\title{
DESCRIPTIVE STUDY OF GROWTH AND DEVELOPMENT IN PRE-SCHOOL CHILDREN IN JEPARA, CENTRAL JAVA
}

\author{
Saekhol Bakri'1), Anisa Rochmah²), Arwinda Nugraheni'), Firdaus Wahyudi'), \\ Bambang Hariyana'), Ani Margawati1) \\ 1)Department of Public Health, Faculty of Medicine, Universitas Diponegoro \\ ${ }^{2)}$ Faculty of Medicine, Universitas Diponegoro
}

\begin{abstract}
Background: A growth and development problem of children means that a child falls either below or above the average range of growth for the child's age, sex, family history, or racial background. A growth disorder prevents the child from reaching the optimum height and weight. It can influence other aspects of the child's mental, physical, or emotional development. This study aimed to describe the growth and development in pre-school children in Jepara, Central Java.

Subjects and Method: A cross sectional study was conducted in Slagi village, Pakis Aji, Jepara, Central Java, from 30 October to 6 November 2018. A total of 120 children under five in Slagi village kindergarten was selected for this study. Study variables were nutritional status, height, and developmental status. The data were collected by interview and observation using growth checklist instrument and developmental pre-screening questionnaire. The data were analyzed descriptively.

Results: Out of 120 children under five, 39 (32.50\%) had malnutrition, 11 (9.16\%) had severe malnutrition, 2 (1.67\%) had overnutrition, and 68 (56.67\%) had good nutrition. Of all 120 children under five, 16 (13.33\%) were short, 3 (2.50\%) very short, and 101 (84.17\%) normal. Of all 120 children under five, 119 (96.67\%) had good, 2 (1.67\%) doubted, and 2 (1.67\%) deviated developmental status.

Conclusion: Malnutrition, stunting, and development problem among children under five are current public health problem in Jepara, Central Java.
\end{abstract}

Keywords: growth, development, children under five, malnutrition, stunting

Correspondence:

Saekhol Bakri. Department of Public Health, Faculty of Medicine, Universitas Diponegoro, Semarang, Central Java. Email: saekhol1985@gmail.com. Mobile: 081390510151.

The $5^{\text {th }}$ International Conference on Public Health Best Western Premier Hotel, Solo, Indonesia, February 13-14, 2019 | 358 https://doi.org/10.26911/theicph.2019.03.61 